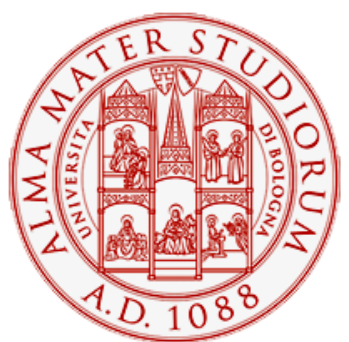

Alma Mater Studiorum - Università di Bologna DEPARTMENT OF ECONOMICS

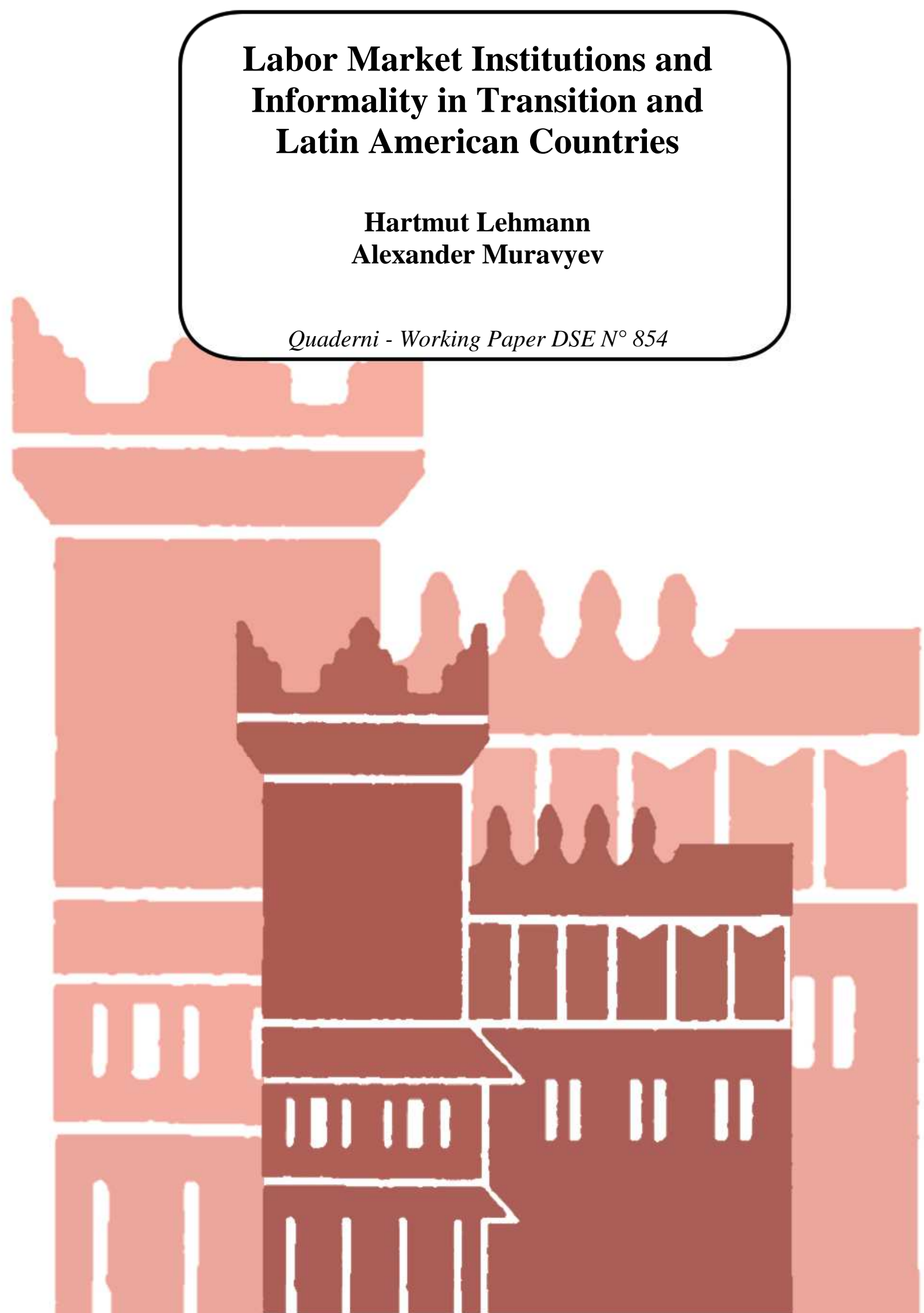




\title{
Labor Market Institutions and Informality in Transition and Latin American Countries*
}

\author{
Hartmut Lehmann (University of Bologna and IZA)** \\ and \\ Alexander Muravyev (St. Petersburg University GSOM and IZA)
}

\begin{abstract}
This paper analyzes, using country-level panel data from transition economies and Latin America, the impact of labor market institutions on informal economic activity. The measure of informal economic activity is taken from Schneider et al. (2010), the most comprehensive study to date. The data on institutions, which cover employment protection legislation (EPL), the tax wedge, the unemployment benefit level, unemployment benefit duration and union density, are assembled at the IZA (transition countries) and the World Bank (LAC countries). We find that a more regulated labor market (higher EPL) increases the size of the informal economy. There is also evidence that a larger tax wedge increases informality. The tax wedge elasticity of informal economy, when evaluated at the sample mean, is rather modest, around $0.1 \%$. Our results are broadly in line with the literature, which identifies labor market regulation and the tax wedge as important drivers of informality.
\end{abstract}

Keywords: Labor market institutions, informality, macroeconometric regressions, transition countries, Latin America.

JEL codes: E24, J21, J42, O17, P20.

November 2012

\footnotetext{
${ }^{*}$ We are grateful to David Robalino for encouraging us to write this paper. We are very grateful to Viviana Mora for carefully assembling the LAC data and to Sebastian Lebig and Florian Plum for collecting and processing the transition economies data. Financial support by the Volkswagen Foundation within the project "The political economy of labor market reform in transition countries: A comparative perspective" is also gratefully acknowledged. The opinions expressed in the paper are exclusively the authors' opinions and do not reflect the opinions of the World Bank or of the institutions with which the authors are affiliated.

** Corresponding author. Email: hartmut.lehmann@unibo.it.
} 


\section{Introduction}

Informality and informal employment pose a major challenge to policy makers in all parts of the world. In this paper we focus on informality in the transition countries of Central and Eastern Europe and the Commonwealth of Independent States as well as in Latin America ${ }^{1}$. While it is difficult to precisely estimate the size of these phenomena, there can be no doubt that in these areas of the world a large part of economic activity is not registered or only partially registered and that many workers enter employment relationships that provide only partial or no protection against unemployment, illness and old age (see, e.g., Slonimczyk 2012 and Lehmann and Pignatti 2007 regarding transition countries and World Bank 2007 regarding Latin America).

There exists a large and growing literature that discusses the reasons why employers and employees are unwilling or unable to work in the formal economy. ${ }^{2}$ The empirical part of this literature provides evidence on the determinants of informality and informal employment looking, for the most part, at individual countries or, when providing a cross-country analysis, focusing at one determinant. In contrast, this paper is to our knowledge the first that uses panel data covering many countries in order to analyze the impact of a set of determinants on informality. We, however, restrict our analysis to the impact of labor market institutions on informality. In particular, using a hand-collected macro-level data set of labor market institutions, we pursue the question whether employment protection legislation (EPL), the tax wedge, the unemployment benefit level, unemployment benefit duration and union density affect the size of the informal economy in the ECA and LAC regions. The paper is interesting for its broad geographic coverage and because of the nature of the data since, having panel data at our disposal, we can avoid some of the pitfalls apparent in much of the empirical literature that is limited to OLS estimation.

\footnotetext{
${ }^{1}$ Employing World Bank nomenclature our geographic coverage extends to the ECA and LAC regions.

${ }^{2}$ For a succinct summary of these reasons, see, e.g., Koettl and Weber (2012).
} 
Informality and informal employment are not only of academic interest, they are actually an important policy issue. There exist equity and efficiency considerations that point to a strong need to vigorously pursue policies that increase the shares of formal economic activity and employment.

It is certainly inequitable if part of the workforce and some firms do not pay their taxes since this implies that those who are formal, whether workers or entrepreneurs, have to bear a disproportionate burden in the financing of public goods that are also of benefit to those being economically active without registration. If the informal part of the economy becomes more substantial this can also mean that governments have to raise taxes and contributions on the formal part and thus have to increase the costs of being formal, which in the final analysis can result in even more informality and a reduced tax base. Furthermore, often workers in informal jobs are severely exploited and are working under conditions that can be hazardous to their health.

Turning to efficiency, most economists maintain that employment in the formal sector is associated with a greater use of physical capital that requires human capital acquisition on the part of the employed workers, while the informally employed often work with little or no physical capital. Since physical and human capital are very important ingredients of growth, an economy with a relatively large formal sector will, ceteris paribus, grow at a more rapid pace than an economy with a smaller formal sector. In the medium run, policies combating informality and informal employment are thus vital for raising income and welfare of low and middle income countries.

These equity and efficiency considerations clearly point to the importance of policies that formalize informal activities. However, the literature on informality provides us with competing paradigms that point to a very complex picture. We need to keep this complexity in mind if we want to discuss policies meant to enhance the emergence of firms and workers from the informal sector and informal employment relationships into regularized economic 
activity and into regular jobs. The existence of the informal segment of the labor market alongside the formal sector and the reasons posited for its existence have given rise to several paradigms in the literature. One key question in the labor market literature for developing countries is whether informal employment or self-employment reflects voluntary choice or is involuntary due to segmentation in the labor market (Guasch 1999).

The traditional dualistic view, going back to Harris and Todaro (1970), sees the informal segment as the inferior sector, the option of last resort. Due to barriers to entry, minimum wages, unions or other sources of segmentation, formal jobs are rationed. Workers in the informal sector are crowded out from the formal sector involuntarily, their wage being less than that in the formal sector. ${ }^{3}$ For example, an increase in the statutory wage in the formal sector will reduce formal employment but lead to a lower informal wage and higher informal employment. During a recession informal employment and output expands because formal employment is reduced, while the informal labor market clears. In this view labor market segmentation between formality and informality is the defining feature of the labor market.

In contrast, in a competitive labor market one would expect workers to be able to move freely between occupations, and for wages (broadly interpreted) to equalize accordingly. In this view the informal and informal labor markets are not segmented, but integrated. Voluntary choice regarding jobs and particular attributes of these jobs, such as flexible hours, working as a self-employed and being one's own boss as a micro-entrepreneur, and not valuing social security benefits, can be the reasons for remaining in or moving to the informal sector (Maloney 1999, 2004; Cunningham and Maloney 2001). Here, contrary to the segmentation case, formal and informal employment are not necessarily negatively correlated over the business cycle.

\footnotetext{
${ }^{3}$ In this school of thought, formal sector jobs not only command higher wages but also provide fringe benefits that are absent with informal sector jobs.
} 
Segmentation and integration of the formal and informal labor markets are two very polar views regarding the interaction of formality and informality. However, as mooted by Fields (1990), it is possible, given the heterogeneity of the informal labor market that these features co-exist in the same labor market. Fields subdivides the informal sector of the labor market into two categories: an 'easy-entry' informal sector, which constitutes the involuntary segment, and an 'upper-tier' informal sector, where barriers of entry persist and in which participation is voluntary. Hence, the labor market is divided into the formal sector, a 'disadvantaged' subsistence-level informal sector and the 'small firm' and micro-entrepreneur informal sector.

The macro evidence presented in this paper is not meant to lead to a confirmation or rejection of the above sketched paradigms. Instead it tries to identify channels through which informal activities and informal employment are affected in general. Thus far such an exercise has not been undertaken in the literature because of a lack of appropriate data. Anticipating our findings, we establish that in most fixed effects (FE) specifications a more regulated labor market increases the size of the informal economy. In some specifications a larger tax wedge also increases the size of informal economic activities. These two results, dominating our empirical evidence, are in line with the literature, which identifies labor market regulation and the tax wedge as important drivers of informality. The other three labor market institutions have little or no predictive power in our regressions.

The rest of the paper has the following structure. The next section discusses definitions of informality, which helps us to better understand the dependent variable in our empirical work. In section 3, we sketch those policies that have an impact on the tax wedge and regulation and thus on informality. This is followed by a section that looks at tax policies, with a focus on the question whether these policies were instrumental in formalizing informal activities that existed in the formal economy. Section 5 is the empirical core of the paper, 
describing the data, the methodology and the main findings of our macroeconometric estimations. A final section gives some policy conclusions.

\section{Using a broad definition of informality}

The definition of informality and the informal sector poses a challenge in itself due to its very nature of not being easily observable (Kanbur 2009; Schneider and Enste 2000; Mead and Morrisson 1996). A broad definition defines the informal economy as including "unreported income from the production of legal goods and services, either from monetary or barter transactions, hence all economic activities that would generally be taxable were they reported to the tax authorities" (Schneider and Enste 2000, pp.78-79). ${ }^{4}$ It is this broad definition that we employ in our macroeconometric analysis in this paper, since informality with this very general definition encompass activities that totally or partially sidestep the taxing authorities. In other words, this definition looks at activities that are $100 \%$ informal, but also at informal activities within the formal economy.

However, we could use a more restricted definition of informality, where a dichotomous situation is analyzed in the labor market, i.e. a situation where workers are either formally or informally employed. This viewpoint essentially restricts itself to the labor market and income generating activities of waged workers or the self-employed with earnings. Even with this restricted view, informality in the labor market is difficult to pin down and can be characterized according to several dimensions, depending on data availability, the legal system present and the nature of the labor market.

There are two reasons why we use the broader definition of informality in our empirical analysis. First, labor market institutions might not only be associated with a dichotomous labor market but might also influence informal activities in the formal sector.

\footnotetext{
${ }^{4}$ This definition excludes unpaid activities such as home production and illicit activities such as drug smuggling. A distinction between licit, illicit, legal and illegal is made in the economic sociology literature definition of informality (Portes and Haller 2005; Portes and Schauffler 1993).
} 
Second, the only data on informality available for the ECA and the LAC regions are the data provided by Schneider, Buehn, and Montenegro (2010). This source uses the above cited broad definition of informality and gives estimates for 162 countries, including Eastern European, Central Asian, and Latin American countries over the years 1999 to 2007.

\section{The impact of policies to lower labor costs and to reduce regulation}

The literature identifies the tax wedge and labor market regulation as potential channels that affect formal employment, unemployment and informal employment. In what follows we therefore discuss how lowering labor costs and decreasing the extent of regulation might increase formal employment and thus reduce unemployment as well as the size of informal activities. In economies where income support for the unemployed is weak or does not exist, unemployment is not always an option for those without a formal job. Consequently, expansion of formal employment translates, at least partially, into a reduction of informal activities. We start off with some simple theoretical predictions and then present some of the salient empirical evidence on the nexus of taxes and regulation and formal employment.

\subsection{A partial equilibrium model of lowering labor costs to employers}

Extending Katz (1998), we provide a simple graphical exposition of the effects of lowering labor costs on employment and wages in figures 1a. - 1.c. These effects of lowering labor costs, which are conceptually equivalent to providing wage subsidies to employers, are only clear-cut in the polar cases when labor supply is perfectly elastic or perfectly inelastic as figures 1.a and 1.b demonstrate. Lowering labor costs implies a rightward shift of the labor demand curve from $L^{d}(w)$ to $L^{d}(w[1-s])$. When labor supply is perfectly elastic this translates into an employment expansion of $\left(\mathrm{L}_{1}-\mathrm{L}_{0}\right)$. For example, we could have a pool of unemployed low skilled workers or low skilled workers in informal jobs. If this pool of the unemployed/informal workers is large or if in addition $\mathrm{w}_{0}$ is a statutory minimum wage, firms 
can expand employment without having to raise the wage. In a second scenario where we assume a perfectly inelastic labor supply the lower labor costs are "passed through" to workers in their entirety leading to a wage hike of $\left(\mathrm{w}_{1}-\mathrm{w}_{0}\right)$ and no additional jobs. Most realistic is the scenario between the two polar cases shown in figure 1.c. where the comparative statics take place in a relatively elastic portion of the labor supply curve. Now we get both an increase in employment and in wages. The relative magnitudes of the effects of lowering labor costs on employment and wages are determined by the labor demand and supply elasticities. For a given labor demand elasticity, the employment effect will be larger the larger the elasticity of effective labor supply, while the wage effect is inversely related to the elasticity of effective labor supply.

Discussion of the empirical evidence on the elasticity parameters leads Katz (1998) to conclude that low skilled workers have a higher elasticity of effective labor supply than skilled workers. The elasticity of labor demand for low skilled workers also seems to be larger in absolute value for low skilled workers. Thus, subsidizing jobs for low skilled workers via direct subsidies or via reducing social security contributions might give larger employment effects than subsidizing jobs for workers of all skill levels. Of course, in the presence of large structural unemployment and/or a minimum wage the employment effects would be particularly large. There are, however, at least two problems with direct targeted subsidies. Employers might not know about these subsidies, and targeting low skilled workers might stigmatize them in the eyes of employers. Of course, when we talk about lowering labor costs via a reduction of social security contributions in particular at the lower end of the wage distribution, these two problems are not present.

\subsection{Empirical evidence on the effects of lowering labor costs to employers}

We report on policies that have attempted to encourage formal job creation through decreasing the tax wedge by direct cutting of labor costs or via job or wage subsidies to firms. 
Since rigorous evaluation studies of such policies are hard to come by we cover a variety of country types in this summary.

There are some special pitfalls in the evaluation of wage or job subsidies or of a decrease of labor costs. If these treatments are general, i.e. applying to all firms and workers it is basically impossible to find a contemporaneous control group and panel data need be used to contrast the average outcome of the treated at the time of the treatment with the average outcome of the treated before the time of the treatment. Even when wage or job subsidies are targeted, e.g. at all low skilled workers, we have the same difficulties in constructing a counterfactual.

The study by Betcherman, Daysal and Pages (2010), which evaluates regionally targeted subsidies in Turkey, is able to establish convincing counterfactuals because they exploit the design of the subsidies and the timing of their introduction in a very apt way. In addition, they match regions as controls that have similar pre-treatment trends of several outcome variables as the treated regions. They thus take account of the point that conditioning on the pre-treatment history and on observables reduces selection biases significantly as e.g. shown in Heckman et al. (1997) in connection with active labor market policies. The careful construction of counterfactuals by Betcherman et al. produces highly credible results. We, therefore, discuss their study in some detail.

The subsidies in Turkey are targeted at low income regions, where the negative characteristics of the Turkish labor market are especially prominent: low job creation, low employment and participation rates and a large share of informal workers. The analyzed subsidies directed at firms and legislated through Law 5084 (2004) and Law 5430 (2005) and containing (i) reductions in employers' social security ; (ii) credits on income taxes on wages; (iii) subsidies on electricity consumption; and (iv) land subsidies were conceived to boost formal job creation and employment. The subsidies are targeted at regions with a specified relatively low average per capita income and are of the marginal type, i.e. the subsidies are 
paid on additional formally employed workers. One of the main differences in the design of the two subsidy schemes consists in the size threshold beyond which a subsidy can be given. Law 5084 foresees a threshold of only 10 employees while Law 5350 raises it to 30 employees.

The authors analyze the following outcome variables: formal employment levels and growth, number of establishments and earnings. Their findings point to differences in employment levels between treated and non-treated regions amounting to roughly 14\% (Law 5350) and $8 \%$ (Law 5084). In terms of employment growth these differences amount to $1.8 \%$ points and $1 \%$ point per month respectively. These results thus show large effects regarding the expansion of formal employment. Turning to the number of establishments, the results are more tenuous since only subsidies emanating form Law 5084 show significant positive effects which are robust to the chosen control group and specification. Subsidies connected to Law 5350 seem to work only at the intensive margin since virtually all specifications show no increase in the number of establishments relative to non-treated regions. Using average real earnings at the regional level, the authors essentially find no "pass through" of earnings, a result that would point to a scenario where the effect of subsidies works through the employment channel only (figure 1.a).

In a complementary study of the Turkish labor market, Papps (2007) investigates the effects of changes in labor costs on employment at the lower and upper ends of the wage distribution, taking advantage of a quasi-natural experiment. This experiment arises because the contribution base of social security contributions for employers and the minimum wage changed in July 2004. By constructing a treatment variable that consists in the difference of total labor costs over two periods for any gross wage under the assumption that a worker holds on to his/her job in both periods, Papps can establish a causal effect of increases in total labor costs on employment. The precise outcome variables are overall employment and employment in registered jobs and are estimated for workers around the minimum wage thus 
ensuring homogeneity of unobservables for the treated and the controls. The author uses an individual panel for the year 2004 and a pseudo-panel (synthetic panel) for the years 2002 through 2005.

The results with the individual panel show small but significant effects of raising labor costs: a 1 percentage point rise in total labor costs lowers the probability of being employed by 0.64 percentage points for those previously employed. At the mean this implies that an increase of $1 \%$ of labor costs lowers the probability of being employed by $0.2 \%$. When the treatment variable is restricted to those who had previously registered jobs, an increase of $1 \%$ of labor costs lowers the probability of being employed by roughly $0.1 \%$ at the mean. The evidence for a shift from formal to informal employment is, however, inconclusive when the individual panel is used. With the synthetic panel the results are economically more significant: raising labor costs by $1 \%$ point lowers employment by roughly $1.1 \%$. If only those are treated who had previously a registered job, this effect is $1 \%$ point. It is also noteworthy that the synthetic panel results show a shift from formal to informal employment by roughly $2 \%$ points when labor costs rise by $1 \%$ point. Finally, since treatment might affect demographic groups to different degrees ${ }^{5}$, Papps documents different treatment levels by gender, residential status (urban-rural), age group and education. Women tend to have higher disemployment rates than men and also tend to shift more frequently from formal to informal employment. The same pattern holds for workers under 30 years of age. In contrast, urban and rural dwellers show divergent behavior in response to a rise in labor costs, since urban workers exit employment, while workers in rural regions, where informal jobs are especially abundant, predominantly shift from formal to informal jobs.

One way to get at the effect of lowering labor costs at the individual level is to produce estimates of labor demand elasticities and of the pass through to wages of decreases in labor costs. This approach is chosen by Taymaz (2006) who estimates constant output labor demand

\footnotetext{
${ }^{5}$ For evidence on this point with respect to ALMP see Kluve, Lehmann and Schmidt (2008).
} 
elasticities for the Turkish manufacturing and construction sectors with a dynamic labor demand equation and a wage equation with an employer social security contributions variable included as a determinant of wages. The coefficient on the social security contributions variable is taken as an estimate of the pass through. Using a GMM-System estimator, Taymaz estimates labor demand elasticities that are between -0.41 and -0.64 and are thus at the higher end of the elasticities found in developed market economies (Hamermesh 1993). Since he also finds relatively fast adjustment speeds in international perspective, his overall results seem to imply that the Turkish labor market is very responsive to changes in labor costs. However, these changes do not necessarily translate into large changes in employment since Taymaz' estimates of the pass through imply that about $70 \%$ of a $1 \%$ point fall in social security contributions translate into higher wages for workers. So, if we assume an average labor demand elasticity of -0.5 a $1 \%$ point lowering of social security contributions will only result in an expansion of employment amounting to $0.15 \%$. Particularly important in our context is the fact that for low wage workers (with wages just slightly below the minimum wage), the pass through estimates are much smaller than for the average worker. So, again we find that targeting workers at the low end of the wage distribution might expand employment most. The note of World Bank (2005a) also emphasizes this point for the EU8 countries.

An important study on the pass through of lowering payroll taxes is Jonathan Gruber's (1997) paper. He takes advantage of a quasi-natural experiment in Chile where at the beginning of the 1980s pension provision was privatized resulting in a dramatic fall of social security contributions paid by employers. Consequently, the change in the payroll tax was clearly exogeneous, making it possible to establish a causal link between the lowering of the payroll tax and changes in wages. To understand Gruber's contribution it is useful to reproduce some of his equations. Labor demand and labor supply are given by the following two equations: 


$$
\begin{gathered}
D=D\left(w\left(1+t_{f}\right),\right. \\
S=S\left(w\left(1-a t_{e}\right)+q w t_{f}\right),
\end{gathered}
$$

where $\mathrm{w}=$ pretax wage; $t_{f}=$ payroll tax rate on firm; and $t_{e}=$ payroll tax rate on workers. Particularly interesting are the parameters a and $\mathrm{q}$. The parameter a is the fraction by which workers discount their payroll tax payments relative to cash income, while $\mathrm{q}$ is the extent to which workers value employer payments relative to cash income. In the case when workers value the social benefits financed by taxation at their full tax cost, $a=0$ and $q=1$. In other words, workers do not consider their own contributions as a cost to be subtracted from their wage since they consider these payments being returned to them as benefits $100 \%$ in the future. By the same token, when workers think that employer contributions will be transformed into benefits for them $100 \%$ in the future, they will treat employer contributions as cash income. The equilibrium solution of this model becomes:

$$
\frac{\frac{d w}{w}}{d t_{f}}=\frac{h_{s} q-h_{d}}{h_{d}-h_{s}\left(1-a t_{e}\right)}
$$

where $h_{s}$ and $h_{d}$ are the supply and demand elasticities. It is easy to show that the right hand side of equation (10) becomes -1 under three conditions:

- Labor supply is perfectly inelastic;

- Labor demand is infinitely elastic;

- There is a complete linkage of benefits and taxes $(\mathrm{a}=0$ and $\mathrm{q}=1)$.

When $\frac{\frac{d w}{w}}{d t_{f}}=-1$, this implies, of course, that the lower payroll tax rate is fully shifted into higher wages, i.e. there is no effect on employment at all. Let us look closer at the third condition, when $\mathrm{a}=0$ and $\mathrm{q}=1$. Assume that the payroll tax is exclusively used to pay benefits to the workers for whom employers pay this tax. Then, when taxes on labor paid the employer 
fall by a certain amount workers perceive this fall as translating in its entirety into a fall of their future benefits. They thus will want to be paid a higher wage that fully compensates for this fall in benefits.

Figure 1.c demonstrates a large albeit not perfect shifting into higher wages of a fall in labor cost (let us say that the government wants to subsidize employment by lowering the payroll tax). The upward shift in the labor supply curve from $\mathrm{L}^{\mathrm{s}}(\mathrm{w})$ to $\mathrm{L}^{\mathrm{s}}(\mathrm{w})$ ' demonstrates that the same number of workers working ex ante are only willing to work ex post if the wage is raised substantially since they interpret the fall in payroll taxes as eating into their future benefits. Hence, the wage increase is now much larger, $\left(\mathrm{w}_{1}{ }^{\prime}-\mathrm{w}_{0}\right)$ compared to $\left(\mathrm{w}_{1}-\mathrm{w}_{0}\right)$, and employment expansion is more modest $\left(\mathrm{L}_{1}\right.$ '- $\mathrm{L}_{0}$ and not $\left.\mathrm{L}_{1}-\mathrm{L}_{0}\right)$. Undertaking a very careful empirical analysis Gruber finds very robust results: lowering payroll taxes does not cause any increase in employment since his regression results imply full shifting of lower taxes into higher wages. These results hold for both white-collar and blue-collar employees.

\subsection{Labor supply effects of lowering the tax wedge}

We now turn to policies which predominantly entail tax incentives on the supply side, focusing first on certain parts of the labor market reforms in Germany ("Hartz-reforms"), which were enacted at the beginning of the century and further developed and fine-tuned in 2003. The parts that interest us here relate to the labor legislation that encourages the increase or the formalization of jobs in the low wage sector, i.e. legislation regarding "mini-jobs" and "midi-jobs".

In the case of mini-jobs, the revised law of 2003 foresees that employees who earn up to $400 €$ per month (mini-jobs) do not have to pay any income tax nor social security contributions, while the employer pays an overall contribution of $25 \%$, above all for pension and health insurance. For mini-jobs in households the employer only pays an overall contribution of $12 \%$. The previously existing limit of 15 hours per week has been abolished. It 
is noteworthy, that employees who in a regular first job pay social security contributions in full are allowed to hold a second mini-job where the same conditions hold as for those workers who only hold a mini-job. In other words, the additional income from the secondary job is not counted in the calculation of social security contributions in connection with the primary job. The revised law of 2003 also reduces transaction costs for employers by having one institution selected for the whole country to which the contributions have to be paid ("Bundesknappschaft"). An important point about mini-jobs in Germany is the fact that potential claimants of mini-job status are very well informed about the rules and regulations of the law.

The revised law also stipulates that workers in the low wage sector who earn between $400.01 €$ and $800 €$ (midi-jobs) face a sliding scale of social security payments, i.e. subsidies of the employee's social security contributions declining with earnings are set in place. Before the revision of the law the full amount of social security contributions and taxes had to be paid by the employee once monthly earnings exceeded the mini-job threshold of $325 €$ (the threshold of mini-jobs before the revision). As a consequence some workers fell into the "social security trap" since a very unfavorable ratio of net to gross wages materialized above the threshold leading to strong incentives to keep earnings below $325 €$ and thus to less hours worked than actually desired by employer and employees. The revised law thus clearly wanted to encourage employment in the middle and higher segments of the low wage sector. In the context of our paper it is also important to stress that one motive for the revised labor market legislation was, of course, the formalization of above all informal secondary jobs or of informal primary jobs in the middle and high segments of the low wage sector. Another declared aim of the legislation was to have mini- and midi-jobs as a bridge to regular employment with earnings above $800 €$.

It is uncontroversial that the revised law on mini-jobs has boosted formal employment in the bottom part of the low wage sector. While the available estimates are based on data 
with some limitations, Fertig and Kluve (2006) find an increase of 1.8 million mini-jobs between April 2003 and June 2004, which they attribute nearly in its entirety to the new labor market legislation. They also establish that men have increased their share of the formal minijobs, which can be explained by a large rise in the incidence of secondary mini-jobs which are predominantly held by men. Ernste and Schneider (2006) state that due to the revised law of 2003, the number of formal mini-jobbers increased from 4.1 to 7.3 million between the spring of 2003 and the beginning of 2006. So, their reading of the data is that having legislation that gives the right incentives to formalize jobs held at the low end of the wage distribution can result in formalization on a large scale. Eichhorst et al. (2012) find a large increase of minijobs that are secondary jobs from 1,437,627 in 2003 to 2,492,559 in 2011, while the number of mini-jobs that provide the only employment for workers rises modestly from 4,554,180 in 2003 to $4,894,322$ in 2011 . This also points to the formalization effect of the legislation of formerly informal jobs.

The employment effects of midi-jobs are a lot more modest. Fertig and Kluve (2006) establish that about $38 \%$ of those in the earnings range between $400.01 €$ and $800 €$ take up the scheme. A large number of potential participants are not aware of the scheme or do not understand the benefits arising from participation. Being able to estimate the levels of jobs in the earnings range in the absence of the scheme (counterfactual scenario) and in its presence, the authors take the difference of the two scenarios as the causal impact of the scheme on employment levels in the stipulated earnings range. They find this impact to amount to roughly 25000 additional employment relationships per quarter. Behind this overall effect is hidden a large heterogeneity with respect to gender, age groups and skill levels. Female workers are strongly overrepresented in midi-jobs. Low-skilled workers between 25 and 39 years of age have a substantially higher likelihood to work in this segment of the low wage sector as have young workers with medium skills. Relative to the counterfactual scenario, older workers with high skills show a slight increase in taking up the scheme. 
One important concern of the analysis discussed by Fertig and Kluve (2006) and by Eichhorst et al. (2012) is the bridging function of mini- and midi-jobs. Both studies find that mini-jobs hardly ever end in jobs that require full payment of social security contributions and taxes, while there is a substantial increase in such employment relationships for workers who previously held midi-jobs. Particularly worrisome is the fact that firms in Germany since the inception of the "Hartz reforms" seem to have substituted regular full-time formal jobs with part-time mini-jobs on a large scale (Eichhorst et al. 2012).

A related important study that analyzes the disincentives to formalize jobs at the lower end of the wage distribution is the study by Koettl and Weber (2012). The authors investigate the role of labor taxation and social benefit design on the disincentives for formal work. They propose a new synthetic measure, the formalization tax rate, which takes into account not only the costs due to additional taxes one has to pay by engaging in the formal economy but also the losses from benefit withdrawal due to formalization. Focusing on some of the European New Member States, they find that the disincentives for formal work as measured by the formalization tax rate are especially high for low-wage earners and that the higher the disincentives the higher is the incidence of informal employment. Their analysis also suggests that existing measures such as the tax wedge may not be sufficient in capturing disincentives for formal work.

\subsection{Labor market regulation and informality}

Employment protection is at the center of labor market regulation. We can understand employment protection as restrictions imposed on firms that prevent them from using labor freely (Addison and Teixeira 2001). A purely neoclassical view of the world invoking "Chatelier's Principle" would thus claim that employment protection a fortiori must result in the inefficient use of labor by firms. On the other hand, employment protection, which comes 
about through national legislation, collective bargaining or judicial process, is put in place to protect workers from undue pressures on the part of employers and to guarantee them reasonable employment and income stability. What interests economists is, of course, how employment protection affects the overall levels of employment and unemployment in the medium run and whether the speed of employment adjustment is affected by employment protection. Since economic theory is ambiguous about these outcomes there has been a large empirical literature trying to answer these questions (for a survey see Addison and Teixeira 2001).

The empirical literature has established that the employment of prime-age male workers is not affected by employment protection. This very robust finding can have implications for the issue of informality and employment protection, since younger and older workers show a greater incidence of informal employment. In other words, very restrictive employment protection might encourage informal employment of these latter groups of workers. Consequently loosening employment protection stipulations for some type of employment might decrease informal employment for these workers. For example, in Spain a major labor market reform in the 1980s abolished severance pay for temporary work and allowed several renewals of temporary jobs. The result of this reform according to Aguirregabiria and Alonso-Borrego (2009) was an overall increase in employment, which was exclusively driven by a rise of temporary employment contracts. So, one can moot that the loosening of regulations for temporary employment decreased informal employment to some degree. However, one also needs to keep in mind that this increase in overall employment was not associated with a rise in labor productivity and in earnings for firms. A counterfactual exercise by these authors that simulated a loosening of employment protection of permanent jobs showed a more substantial increase in overall employment and in labor productivity. The example of Spain also shows that changing regulations regarding the core of the workforce is politically difficult to implement and indicative of the situation that in OECD countries 
reforms of employment protection are predominantly focused on employment of the contingent type. As already mentioned, loosening the regulation of contingent employment relationships might, on the other hand, contribute to the formalization of many informal jobs.

The empirical literature dealing directly with the impact of loosening labor market regulation in general and employment protection in particular on informal employment or informality has not produced robust and thus credible results. The work done under the aegis of the Institute of the German Economy has produced an overall index of regulation and an index of labor market regulation for most of the OECD countries (Enste and Hardege 2007). The overall index has five components: regulation in product, capital and labor markets, regulation in education and innovation as well a good governance index taking into account the quality of institutions within which the economy operates. The authors make the salient point that any economy needs regulation implemented by public institutions; what matters, though, is that regulatory legislation does not create strong incentives to avoid this regulation. With the help of macro data Ernste and Hardege perform simple beta regressions in order to show the influence of various factors and of the overall regulation index on the size of the informal economy. They demonstrate that even if one controls for general tax burden, tax ethics, per-capita-income and the unemployment rate, the overall regulation index remains highly significant and has a large positive beta coefficient $(0.351)$. They repeat the same exercise with the regulation index for the labor market as an explanatory variable and get very similar results, i.e. a significant beta coefficient of 0.221 . Since these beta regressions are based on OLS regressions with two averaged data points, these regressions show correlations rather than causal effects running form regulation to the size of the informal economy. Nevertheless, these regression results are interesting in that they state that OECD countries with high regulation ceteris paribus have a larger informal economy. Consequently reducing the strictness of overall regulation and of regulation in the labor market should diminish the size of the informal economy. 
Studies, which are econometrically rigorous and use firm or household micro data, have investigated regulation and employment protection and informality with a special focus on developing countries, in particular Latin America. These studies, summarized in Kucera and Roncolato (2008), show contradictory results, with some analyses suggesting a positive relationship between labor market regulation and employment protection and the level of informal employment, other studies a negative relationship and some studies no relationship at all. So the jury is still out on whether labor market regulation affects informal activities in the LAC region.

\section{Taxation and informality within the formal sector}

In many countries undeclared work by dependent employees or by the self-employed who do operate in the formal economy is a wide-spread phenomenon (see, e.g., Brookmann et al. 2010 and Sabirianova Peter 2009). In this section, we summarize empirical studies that have analyzed the effect of a flat tax reform on the informal economy.

The paper "Myth and Reality of Flat Tax Reform: Micro Estimates of Tax Evasion Response and Welfare Effects in Russia" by Gorodnichenko, Martinez-Vazquez and Sabiarianova Peter (2009) uses the flat tax reform in Russia to establish the effect with respect to tax evasion and the productivity effect of the Russian tax reform that imposed a flat tax of 13 percent on all levels of income as of 2001. The authors employ state-of-the-art methods to derive measures of tax evasion and to get convincing empirical estimates of the above mentioned effects. The authors use various measures of the consumption-income gap to get at the level of tax evasion in Russia and show very convincingly that these large positive gaps cannot be attributed to dis-saving. In multivariate regressions they demonstrate that the factors driving these gaps are the same factors that are established when tax evasion is directly tackled in "Taxpayer Compliance Measurement Program" studies. Hence the consumptionincome gap in Russia can be taken as a good proxy for tax evasion. 
Using the household panel of the Russian Longitudinal Monitoring Survey (RLMS) the authors then proceed to establish the "treatment effect" of the tax reform with respect to tax evasion using difference-in-differences and regression discontinuity approaches. Households whose incomes even before the reform were taxed by 13 percent belong to the control group while households whose tax rates were higher before the reform belong to the treated group. Essentially subtracting the difference of the consumption-income before and after the reform of the treated from the difference of the control group establishes the effect of the reform on tax evasion as long as confounding (endogeneity) problems are minimized. The authors minimize these problems by using the post-reform income to identify the control and treatment groups. Going through several estimation methods and many robustness checks the authors establish a large treatment effect of the tax reform in Russia with respect to tax evasion as they find that income grows by roughly 11 percent more than consumption.

The paper also undertakes welfare analysis by asking the question whether lower tax rates give a supply side boost to the economy. The authors show that in the presence of large tax evasion the positive effects of tax reform might be overstated by conventional approaches. Their consumption based approach shows that the productivity effect of tax reform is small relative to the tax evasion effect, i.e. they show that an increase in income following tax reform is not predominantly driven by an increase in labor supply or other supply side factors but is driven by an increase in tax compliance. In other words pre-reform undeclared, i.e. informal activities are formalized by Russian workers.

The paper by Slonimczyk (2012) directly investigates the impact of the Russian tax reform on informal activities, using the Russian Longitudinal Monitoring Survey, covering the period 1998-2009 and taking advantage of a special supplement on informality fielded in 2009. Slonimczyk takes advantage of the fact that some workers are not affected by the reform, i.e. that their pre-reform tax rate was 13 percent or less, while other workers experience a strong reduction in their tax rate from 21 or 31 percent to 13 percent. This latter 
group comprises the treated, the former group the controls. Taking various manifestations of informality as the dependent variable he then analyzes whether there is a difference in the change of informality pre- and post-reform among the two groups, i.e. he estimates the difference-in-differences (DID) in the labor market outcomes of interest, performing OLS, fixed effects regressions as well as using a semi-parametric matching DID estimator.

The study finds that the tax reform reduced significantly the incidence of informal employment. The largest reduction is observed on the prevalence of informal irregular activities and for the individuals in the top income brackets who benefited the most from the reform.

Sabirianova Peter (2009) gets qualitatively similar results when estimating the introduction of a flat tax regime on the size of the informal economy, employing a panel data set of 170 countries that spans 25 years. She finds that imposing a flat tax reduces informal activities especially at the top of the income distribution. However this effect only works in the first year after the introduction but vanishes in the long run. The author also establishes that in countries with poor institutions tax cuts do not produce any discernible impact.

\section{Empirical analysis with macro data}

\subsection{Data sources and descriptive statistics}

\section{$\underline{\text { Data sources }}$}

Our analysis is based on data from several principal sources. The first source is a database of the IZA Program Area 'Labor markets in emerging and transition economies', which is a new hand-collected dataset that provides essential information about the evolution of labour markets in the countries of Central Europe and Central Asia. It includes 27 countries of the region and spans 4 years, 1995, 1999, 2003, and 2007. The database contains four key variables characterizing labour market outcomes and six key variables describing labour 
market institutions. The latter include employment protection legislation (OECD version II), expenditures on active labor marker programs, tax wedge, unemployment benefit size (measured as average benefit to average wage), unemployment benefit duration, and union density. There are 71 observations with complete data on these 10 variables, corresponding to 23 countries. Details about the variables included in the database are shown in the Appendix.

The second source is new data on labor market institutions in Latin American countries provided by the World Bank. This database contains the same institutional variables as the mentioned IZA database except for expenditures on active labor market policies, which are omitted for data availability reasons. We thus have variables characterizing employment protection legislation (OECD version II), the tax wedge, unemployment benefit size and duration, as well as union density. This information is available for 25 countries and 3 years, namely 1999, 2003 and 2007. The only notable difference with regard to the IZA dataset is in measuring unemployment benefit size. Due to information constraints, for Latin American countries it is measured as the replacement ratio during the third month in unemployment. Further details on this source are available from the authors upon request.

The third building block is data on the size of the informal economy taken from the paper by Schneider, Buehn, and Montenegro (2010). This source provides estimates for 162 countries, including Eastern European, Central Asian, and Latin American countries over 1999 to 2007. This is a unique dataset providing comparable estimates for most countries of the world based on the MIMIC estimation method.

Finally, we have added some key macroeconomic variables from the World Bank database (http://data.worldbank.org/), such as employment to population ratio, GDP growth rate and inflation. These variables are commonly used in macro-labor regressions for various robustness checks. 


\section{$\underline{\text { Descriptive statistics }}$}

Descriptive statistics for the key variables used in subsequent analysis is shown in Table 1. Panel A of Table 1 provides information for the pooled sample of transition economies and Latin American countries, and Panels B and C describe the two sub-samples separately.

As can be seen from the data in Table 1, the size of the informal economy (variable INFORMAL) is quite large in the countries sampled (about 38\%), and does not differ much across the two sub-samples (37\% in transition economies and 39\% in Latin America). These numbers are considerably higher than in the OECD or EU (see Schneider et at. 2010). Importantly, the variables measuring labor market institutions and policies are, in general, at lower levels than in mature market economies, especially of Western Europe. For the entire sample, the EPL appears to be relatively flexible, at the level of 1.56 (variable EPL). This is much less than in the OECD or EU, where EPL exceeds 2.0. The tax wedge (variable TAX) is non-negligible, although still less than in mature market economies. Unemployment benefit (variable BENEFIT) is rather small, and its duration is just 7 months (variable BNFT_DUR), on average. Again, this is much less than in most high income countries, especially of Western Europe. Union density (variable DENSITY) is at the level of 32\%, which is considerable.

The picture becomes more nuanced when we look at the two sub-samples separately. In particular, the two groups of countries appear to be similar with respect to only one institutional variable, namely the tax wedge. As regards other variables measuring labor market institutions and policies, there are notable differences between transition economies and Latin American countries. In particular, the EPL, benefit size and duration, as well as union density all appear to be much higher in the former group of countries as compared with the latter group. As these variables are usually associated with better protection of workers, 
we conclude that labor market institutions seem to be more labor-friendly in transition countries as compared with Latin American countries. ${ }^{6}$

Table 2 shows pairwise correlation coefficients between the key variables. Again, we present information for the pooled sample (Panel A) and the two regional sub-samples (Panels B and C). Statistical significance (at the 5\% level) of the correlation coefficients is marked by asterisks. As can be seen from raw correlations in Panel A, the informal economy is negatively and statistically significantly correlated with all institutional variables save union density, where the correlation is positive and statistically significant. Some of these correlations appear to be rather counterintuitive, for example, the negative correlation between the tax wedge and informal economy. This suggests the importance of more sophisticated techniques of analysis aimed at netting out the effect of confounding factors and establishing causal links between the variables of interest.

Panels $\mathrm{B}$ and $\mathrm{C}$ show some differences in raw correlations between the informal economy and labor market institutions across the two sub-samples. In both sub-samples, the correlation of the informal economy with EPL is negative, but statistically insignificant. In transition countries, the size of the informal economy is negatively correlated with the tax wedge and benefit size, and positively correlated with union density. For Latin American countries, the only statistically significant correlation is with unemployment benefit duration (negatively signed).

\subsection{Methodology}

Our analysis of the link between the size of the informal economy on the one hand and labor market institutions and policies on the other hand draws heavily on the standard macro-

\footnotetext{
${ }^{6}$ A caveat is due. There may be further aspects of the institutional environment that are not properly reflected in the variables presented. These include, for example, law enforcement, eligibility rules for unemployment benefits, and bargaining and coverage patterns. We nevertheless believe that the consistent pattern appearing in the five key variables available justifies our general conclusion concerning the two regions.
} 
regressions proposed in the seminal study by Nickell (1997). In that study, labor market outcome variables are related, in a panel regression framework, to a set of variables measuring institutions and policies, as well as by the change in inflation. We proceed in an essentially similar fashion by considering, in the baseline specification, five variables characterizing institutions and policies.

We note that our results do not necessarily have a causal interpretation as both institutions and policies may be shaped by labor market outcomes, for example, via the mechanism of elections (Blanchard 2006). Nevertheless, we try to address endogeneity (at least some of its sources) by controlling for omitted factors (including unobserved characteristics of countries) using random- or fixed-effects specifications of our regression model. These are necessary as the paucity of the degrees of freedom does not allow inclusion of many potentially relevant explanatory variables. The baseline (pooled OLS) regression equation can then be written in the following way:

$$
\text { INFORMALITY }_{i t}=\alpha+\beta_{1} \text { EPL }_{i t}+\beta_{2} \text { TAX }_{i t}+\beta_{3} \text { BENEFIT }_{i t}+\beta_{4} \text { BNFT }_{-} D U R_{i t}+\beta_{5} \text { DENSITY }_{i t}+\varepsilon_{i t}
$$

where index $i$ denotes countries and index $t$ denotes time, $t \in\{1999,2003,2007\}$, INFORMAL stands for the size of the informal economy as measured in Schneider et al. (2010), EPL measures the strictness of employment protection legislation, TAX is the tax wedge on labor, BENEFIT stands for the average unemployment benefit replacement rate, BNFT_DUR stands for the maximum duration of unemployment benefits, DENSITY measures union density, and $\varepsilon$ is a white noise disturbance. We then proceed by adding country and time effects. ${ }^{7}$ Because macro-trends in the two very remote regions may be very different, we allow for different time trends in transition and Latin American countries. We then consider additional macro controls: change in inflation and cumulative growth of GDP in

\footnotetext{
${ }^{7}$ As much of the previous studies, we do not apply logarithmic transformation to the dependent variables in the model.
} 
the years before labor market outcomes are measured. Last but not least, we estimate the regressions separately for each region, transition economies and LAC countries.

As can be seen from the specification of equation (4), one substantial difference from the study by Nickell (1997) and subsequent studies (e.g., Lehmann and Muravyev 2012) is that we do not employ variables measuring expenditures on active labor market policies. This is both due to data constraints as well as the absence of a clear theoretical link between informality and active labor market programs. ${ }^{8}$ In addition, we do not include variables measuring union coverage rates and bargaining type - again, mostly for data reasons, but also due to the difficulties in interpreting these variables in less developed countries. ${ }^{9} \mathrm{We}$, however, believe that we capture the essential aspects of wage setting with our union density variable since it is regarded as the most important of the related factors (Eichhorst, Feil, and Braun 2008).

\subsection{Empirical results}

We start with the results of estimating the baseline regressions using three alternative specifications: OLS, random-effects (RE), and fixed-effects (FE). Table 3 shows the results. The regression in Column 1 is estimated using OLS. In addition to key explanatory variables, we add a dummy for Latin American countries in order to account for potential differences between the two sub-samples. The results suggest a negative and statistically significant effect of the tax wedge on informal economy and a positive effect of union density. There is also a negative (albeit marginally statistically insignificant) coefficient on the EPL, suggesting, if taken at face value, that stricter employment protection is associated with less informality. We have serious doubts regarding these results. In particular, the first result implying that

\footnotetext{
${ }^{8}$ When we estimated the determinants of the size of the informal economy separately for transition countries and included ALMP expenditures (available only for this group of countries), this variable had no predictive power in any of the specifications. These results are available upon request.

${ }^{9}$ For example, how would one interpret data on bargaining in a country where trade unions with high membership rates are effectively controlled by the government? It is therefore no surprise that the World Bank did not provide statistics on the coverage rates and bargaining type in the CIS countries (World Bank 2005b).
} 
increasing taxes reduces informality is especially counterintuitive in the light of the theoretical considerations and the discussed empirical evidence on the effects of changing the tax wedge. We therefore explore, in Columns 2 and 3, whether it may be endogenous, e.g. driven by omission of important factors at the country level.

Column 2 shows the results obtained using the random-effects estimator. Interestingly, the coefficients on both EPL and tax wedge change signs (to positive), but remain statistically insignificant. The coefficient on union density loses statistical significance. Instead, we observe negative and statistically significant (at the $10 \%$ level) coefficients on unemployment benefit size and duration. This implies, ceteris paribus, that more generous unemployment benefit schemes are associated with lower informality.

Next, Column 3 shows the results from the fixed-effects estimation. The picture is now very different to what we have seen in Columns 1 and 2. In particular, both EPL and tax wedge are now positively and statistically significantly associated with informality. In other words, stricter employment protection as well as higher tax wedge on labor increases the size of the informal economy. The coefficients on the other variables are statistically insignificant, although the corresponding t-statistics are usually greater than unity in absolute value. Note that the coefficient on the dummy for LAC countries cannot be estimated in this specification as the respective effect is now subsumed in country fixed-effects.

Beneath the main estimation results in Column 2 and 3 we report standard diagnostic tests, namely the Breusch and Pagan test for random effects and the Hausman test. Both are rejected at conventional significance levels. The rejection of the first test suggests the importance of unobserved time-invariant effects at the country level (and thus, inferiority of OLS specification), the rejection of the latter implies inconsistency of the random effects (and, of course, OLS) estimator. Therefore, the fixed-effects estimator appears to be the only one which can potentially deliver consistent estimates of the effect of labor market institutions on 
the size of the informal economy. In what follows we therefore rely on this estimator and skip OLS and random-effects specifications altogether. ${ }^{10}$

In Table 4 we expand the analysis presented in Table 3 by adding time effects (which are supposed to control for general macro-trends) and testing the importance of missing observations as well as of differences in measuring unemployment benefit size between the two groups of countries. For comparison purposes, Column 1 reproduces the FE specification from Table 3, which is now our baseline specification. Column 2 of Table 4 shows the results when the baseline specification is augmented with time effects (assumed common for both regions). Here and later in the analysis the base year is 1999 . The coefficients on the time dummies, therefore, can be interpreted as showing the dynamics of informality net of the effect of the institutional variables. In particular, the regression in Column 2 suggests a monotonic decline in informality in the sampled countries between 1999 and 2007. Regarding the key variables of interest, the coefficients on both EPL and TAX lose statistical significance. Instead, we observe a negative and statistically significant coefficient on BENEFIT suggesting that informality decreases with more generous unemployment benefits (higher replacement ratios). The regression in Column 3 differentiates between the macro trends in transition and LAC countries. The results suggest that these trends were not the same in the two regions of the world: while there seems to have been a steady decrease in informality in transition countries, informality appears to have peaked in LAC countries in 2003. However, the coefficients on the main variables of interest are barely affected by this change in specification.

In Column 4, while controlling for differential macro-trend in the two regions, we drop the density variable from the regression. The rational is the presence of too many missing observations for this specific variable in LAC region (see Table 1 Panel C). The results are not

\footnotetext{
${ }^{10}$ The diagnostic tests reject OLS and random-effects estimation methods also in the other specifications that we consider below.
} 
very different from the previous specifications. The negative coefficient on BENEFIT loses statistical significance; all the other institutional variables are insignificant, too.

Finally, in Column 5 we bring back union density, but now differentiate between benefits size in transition and LAC countries (because they are measured somewhat differently). This robustness check brings no visible changes to the previously reported results.

The regressions reported in Table 5 introduce several additional control variables: employment to population ratio (variable EMP-POP-RAT, the data are taken from the WB open sources), GDP growth in period t-1 (variable GDP_GR), and change in inflation in year t relative to year t-1 (variable INFL_CH). ${ }^{11}$ There are two baseline specifications to which these extra controls are added - the regression without any time effects (Column 3 Table 3) and the regression with differential trends (Column 3 Table 4). Overall, the results in Table 5 suggest the high importance of lagged GDP growth for informality, with higher growth rates associated with decrease in informal economic activity. Employment-to-population ratio matters in some specifications while change in inflation has little relevance - at least in our regressions - for informality. Looking at the coefficients on the institutional variables, one may note that four out of five of them are statistically significant, at least in some specifications. The only consistently insignificant institutional variable is union density, DENSITY. The coefficients on the other variables have the expected signs. In particular, higher EPL as well as higher tax wedge are associated with an increase in informality. Unemployment benefit size and duration, are in contrast, negatively related to informal economic activity.

In Table 6 we analyze the effects of labor market institutions on informal economic activity separately for two regions, transition and LAC countries. Odd columns show the

\footnotetext{
${ }^{11}$ We have also experimented with longer lags. They have worse predictive power while the main coefficients of interest stay similar to those reported in the paper.
} 
results for transition economies and even columns - for LAC countries. In regressions with LAC countries we have to exclude union density from the list of regressors for otherwise the number observations drops below 30, which makes the results unreliable. The paucity of the degrees of freedom in the two sub-samples makes most of the coefficients statistically insignificant. However, some of the results from the previously reported tables survive. In particular, the regression in Column 3 confirms the importance of EPL in transition economies and the regression in Column 4 confirms the importance of unemployment benefit duration in LAC countries.

From both research and policy perspectives it may be important to characterize the estimated effects quantitatively, as is usual, in terms of elasticities. Below we provide such an assessment for several institutional variables based on the results in Table 5. Note that since the models estimated are linear, the elasticities will differ for different values of the independent variables. We follow the common approach and evaluate them at the sample means. Assuming the coefficient on EPL equal to 0.9 (the rough average in the regressions where this coefficient is statistically significant) and given the sample average for EPL at the level of 1.56 and the sample average for INFORMAL at 38, the elasticity of EPL with respect to the informal economy turns out to be about 0.04 . In other words, reducing EPL by $1 \%$ will result in a decrease of informality by $0.04 \%$. Similarly, if we assume the coefficient on the tax wedge variable equal to 0.1 and take the sample average for INFORMAL (38) and TAX (39.5), the elasticity of the tax wedge with respect to informal economic activities (evaluated at the sample mean) is close to 0.1 . In other words, decreasing the tax wedge by $1 \%$ leads to a drop in informality by $0.1 \%$. For the unemployment benefit, the sample mean is 20.5 , and the coefficients - when statistically significant - average -0.06 . These numbers suggest the elasticity of unemployment benefit with respect to informal economic activities to be about $0.03 \%$. In other words, raising unemployment benefit by $1 \%$ will result in the decrease of informality by a mere $0.03 \%$. 


\section{Conclusions}

Using unique hand-collected country level data on labor market institutions in transition and Latin American countries this paper provides some first estimates on the impact of EPL, the tax wedge, benefit levels and duration as well as union density on informality in these two regions of the world. Our results suggest that mainly two labor market institutions matter for informality, confirming the main findings of the literature, which identifies taxes and labor market regulation as important determinants of the size of the informal economy.

Our quantitative assessments show that the tax wedge produces the highest positive elasticity. Hence, lowering the tax wedge might be one of the important policy instruments in combating informality. The positive impact of EPL on informality, on the other hand, while significant is very small.

Our analysis also strongly suggests that cross-country studies of determinants of informality should be based on panel data which allow controlling for unobserved country effects. The results from our OLS specifications (where unobserved country effects are not controlled for) turn out to be dramatically different from what we obtain in the fixed-effects regressions. 


\section{References}

Addison, J. T. and P. Teixeira (2001), "The Economics of Employment Protection", IZA Discussion Paper N. 381 .

Aguirregabiria, V. and C. Alonso-Borrego (2009), "Labor Contracts and Flexibility: Evidence from Labor Market Reform in Spain”, Working Paper 09-18, Economic Series (11), February.

Betcherman, G., N. M. Daysal and C. Pages (2010), "Do Employment Subsidies Work? Evidence from Regionally Targeted Subsidies in Turkey”, Labour Economics, in press.

Blanchard, O. (2006),'European Unemployment: The Evolution of Facts and Ideas”, Economic Policy, 21(45): 5-59.

Boockmann, Bernhard und Johannes Rincke (2005), "Wirksamkeit der Bekämpfung der Schwarzarbeit durch die 'Finanzkontrolle Schwarzarbeit'"("The Efficacy of Fighting Undeclared Work through 'Finanzkontrolle Schwarzarbeit'”), ZEW, Mannheim.

Boockmann, Bernhard, Döhrn, Roland, Groneck, Max and Hans Verbeek (2010), Abschätzung des Ausmasses der Schwarzarbeit (The Estimation of the Extent of Undeclared Work), Tübingen and Essen.

Cunningham, W. V. and W. F. Maloney (2001), "Heterogeneity among Mexico's Microenterprises: An application of Factor and Cluster Analysis", Economic Development and Cultural Change, 50, 131-156.

Eichhorst, W., M. Feil and C. Braun (2008) What Have We Learned? Assessing Labor Market Institutions and Indicators, IZA Discussion Papers No. 3470

Eichhorst, W., Hinz, T., Marx, P., Peichl, A., Pestel, N., Siegloch, S., Thode, E. and V. Tobsch (2012), "Gerinfuegige Beschaeftigung: Situation und Optionen“ (in German), IZA Research Report No. 47, October.

Enste, D. and S. Hardege (2007), "Regulierung und Schattenwirtschaft”, in IW-Trends, 34 Jahrgang (1).

Enste, D. and F. Schneider (2006), „Welchen Umfang haben Schattenwirtschaft und Schwarzarbeit? Ein Versuch zur Lösung des Rätsels“, in Zeitschrift für Wirtschaftspolitik, 86. Jahrgang (3).

Fertig, F. and J. Kluve (2006), „Alternative Beschäftigungsformen in Deutschland: Effekte der Neuregelung von Zeitarbeit, Minijobs und Midijobs“, in Vierteljahreshefte zur Wirtschaftsforschung 75 (3), 97-117.

Fields, G. S. (1990), "Labour Market Modelling and the Urban Informal Sector: Theory and Evidence”, in David Thurnham, Bernard Salomé and Antoine Schwarz (Eds.), The Informal Sector Revisited, OECD, Paris.

Fields, G.S. (2006), "Modeling Labor Market Policy in Developing Countries: A Selective Review of the Literature and Needs for the Future", Ithaca, New York, Mimeo.

Gasparini, L. and L. Tornarolli (2007), "Labor Informality in Latin America and the Caribbean: Patterns and Trends from Household Survey Microdata", CEDLAS Working Paper February 2007.

Gorodnichenko, Y., J. Martinez-Vazquez and K. Sabiarianova Peter (2009), "Myth and Reality of Flat Tax Reform: Micro Estimates of Tax Evasion Response and Welfare Effects in Russia", in Journal of Political Economy, Vol. 117 (3), 504-554.

Gruber, J. (1997), "The Incidence of Payroll Taxation: Evidence from Chile", in Journal of Labor Economics, Vol. 15 (3), 72-101.

Guasch, J. L.. (1999), "Labor Market Reforms and Job Creation: The Unfinished Agenda in Latin America and the Caribbean Countries", World Bank, Washington D.C..

Harris, J.R. and M.P. Todaro (1970), "Migration, Unemployment and Development: A Two Sector Analysis", American Economic Review, 60, 126-142.

Kanbur, R. (2009), “Conceptualizing Informality: Regulation and Enforcement”, Unpublished Working Paper. 
Katz, Lawrence F. (1998), "Wage Subsidies for the Disadvantaged", in Richard B. Freeman and Peter Gottschalk (Eds.), Generating Jobs: How to Increase Demand for Less-Skilled Workers, Russell Sage Foundation, New York.

Kluve, J., H. Lehmann and C. M. Schmidt (2008), "Disentangling Treatment Effects of Active Labor Market Policies: The Role of Labor Force Status Sequences”, Labour Economics, 15, 1270-1295.

Koettl, J. and M. Weber (2012), "Does Formal Work Pay? The Role of Labor Taxation and Social Benefit Design in the New EU Member States”, Research in Labor Economics, 34, 167-204.

Kucera, D. and L. Roncolato (2008), "Informal Employment: Two Contested Policy Issues", in International Labour Review, Vol. 147 (4), 321-348.

Lehmann, H. and A. Muravyev (2012), Labour Market Institutions and Labour Market Performance: What Can We Learn from Transition Countries?, Economics of Transition, 20(2): 235-269.

Lehmann, H. and N. Pignatti (2007), "Informal Employment and Labor Market Segmentation in Transition Economies: Evidence from Ukraine”, IZA Discussion Paper No. 3269.

Maloney, W. F.. (1999), "Does Informality Imply Segmentation in Urban Labor Markets? Evidence from Sectoral Transitions in Mexico", World Bank Economic Review, 13, 275-302.

Maloney, W. F.. (2004), “Informality Revisited”, World Development, 32, 1159-1178.

Mead, D. C. and C. Morrison (1996), “The Informal Sector Elephant”, World Development, 24(10), 1611-1619.

Nickell, S. (1997), "Unemployment and Labor Market Rigidities: Europe versus North America", Journal of Economic Perspectives, 11(3): 55-74.

Organization for Economic Cooperation and Development (2008), Employment Outlook, Paris, France.

Papps, K.L. (2007), “The Effect of Social Security Taxes and Minimum Wages on Employment Growth in Turkey", Background Paper for the World Bank, Oxford.

Portes, A. and W. Haller (2005), “The Informal Economy”, in Neil J. Smelser and Richard Swedberg (Eds), The Handbook of Economic Sociology, Princeton and Oxford, Princeton University Press.

Portes, A. and R. Schauffler (1993), "Competing Perspectives on the Latin American Informal Sector", Population and Development Review, 19(1), 33-60.

Saavedra, J. and A. Chong (1999), "Structural Reform, Institutions and Earnings: Evidence from the Formal and Informal Sectors in Urban Peru”, Journal of Development Studies, 35, 95-116.

Sabiarianova Peter, K. (2009), "Income Tax Flattening: Does it Help to Reduce the Shadow Economy?", IZA Discussion Paper No. 4223, June.

Schneider, F., A. Buehn and C. E. Montenegro (2010), Shadow Economies all over the World: New Estimates for 162 Countries from 1999 to 2007, unprocessed.

Schneider, F. and D. H Enste (2000), "Shadow Economies: Size, Causes and Consequences", Journal of Economic Literature, 38 (March), 77-114.

Slonimczyk, F. (2012), "The Effect of Taxation on Informal Employment: Evidence form the Russian Flat Tax Reform”, Reasearch in Labor Economics, 34, 55-100.

Taymaz, E. (2006), "Labor Demand in Turkey”, Background Paper for the World Bank, unprocessed.

World Bank (2005a), "Labor Taxes and Employment in the EU-8", Quarterly Economic Report EU-8, Washington, DC. 
World Bank (2005b), "Enhancing Job Opportunities: Eastern Europe and the Former Soviet Union, Washington D.C.

World Bank (2007), Informality: Exit and Exclusion, Washington D.C.. 


\section{FIGURES}

Figure 1 Lowering the tax wedge to the employer (employer subsidies) - partial equilibrium effects.

$\underline{\text { 1.a Labor supply infinitely elastic }}$

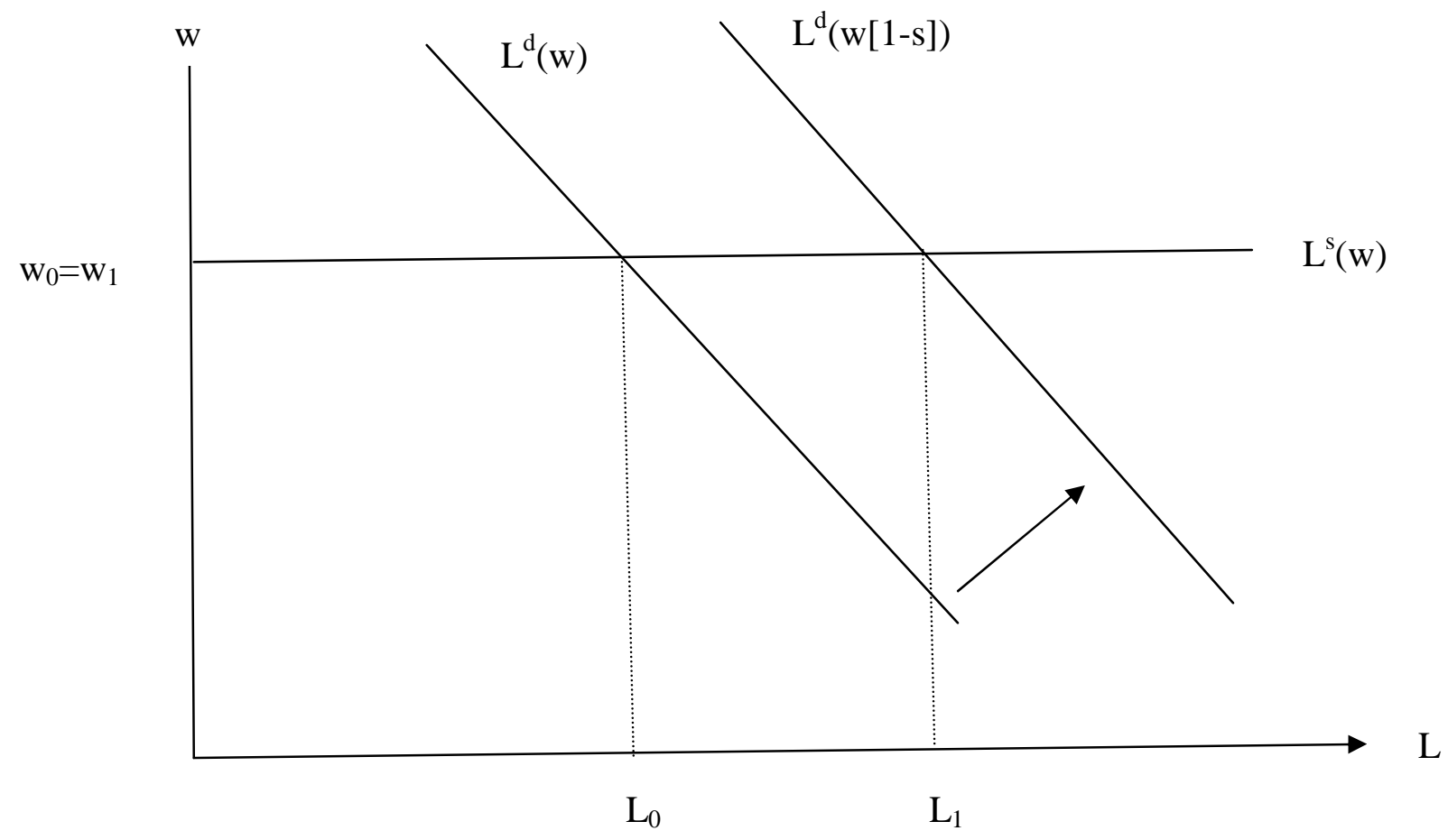

$\underline{1 . b \text { Labor supply perfectly inelastic }}$

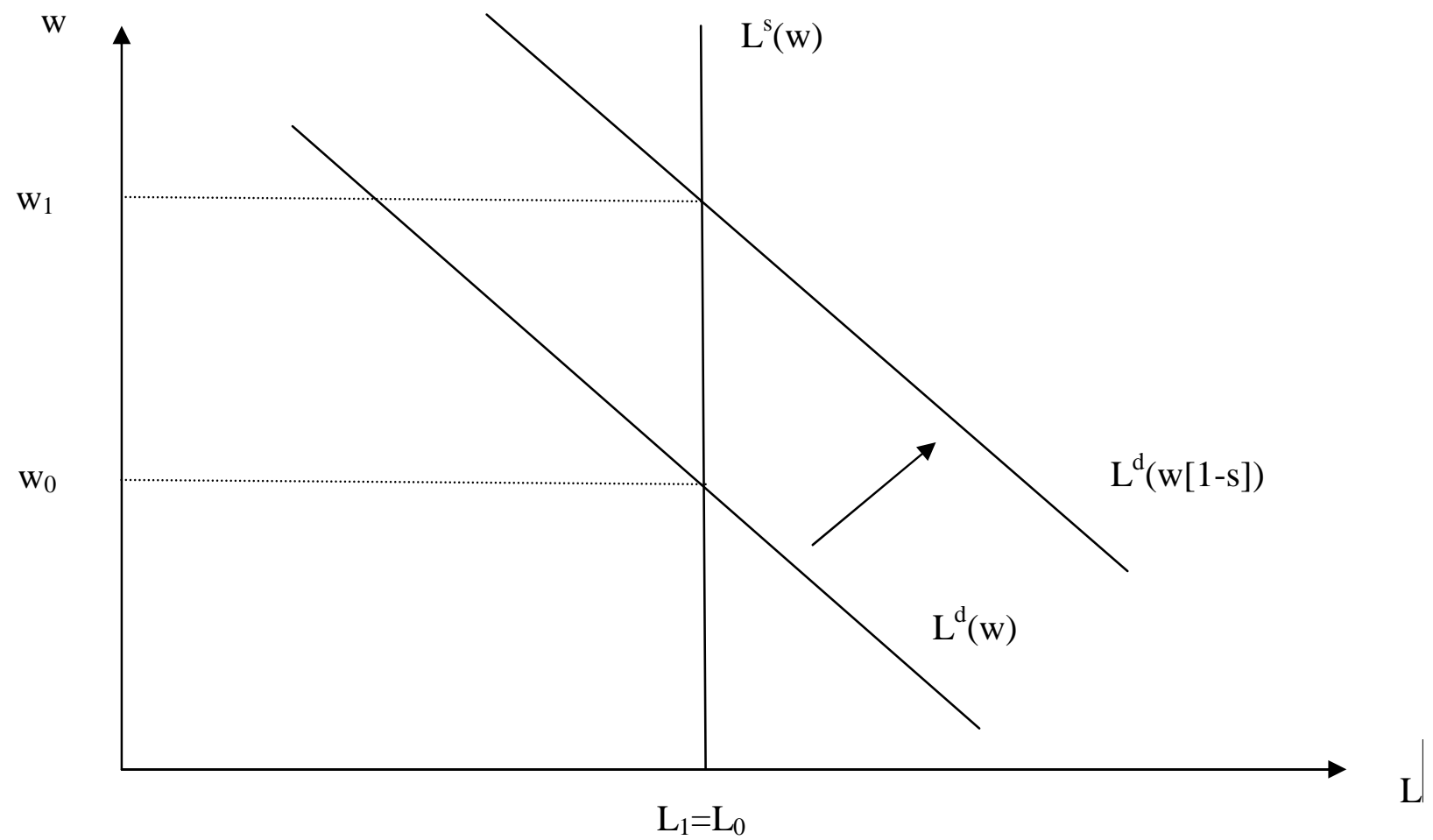




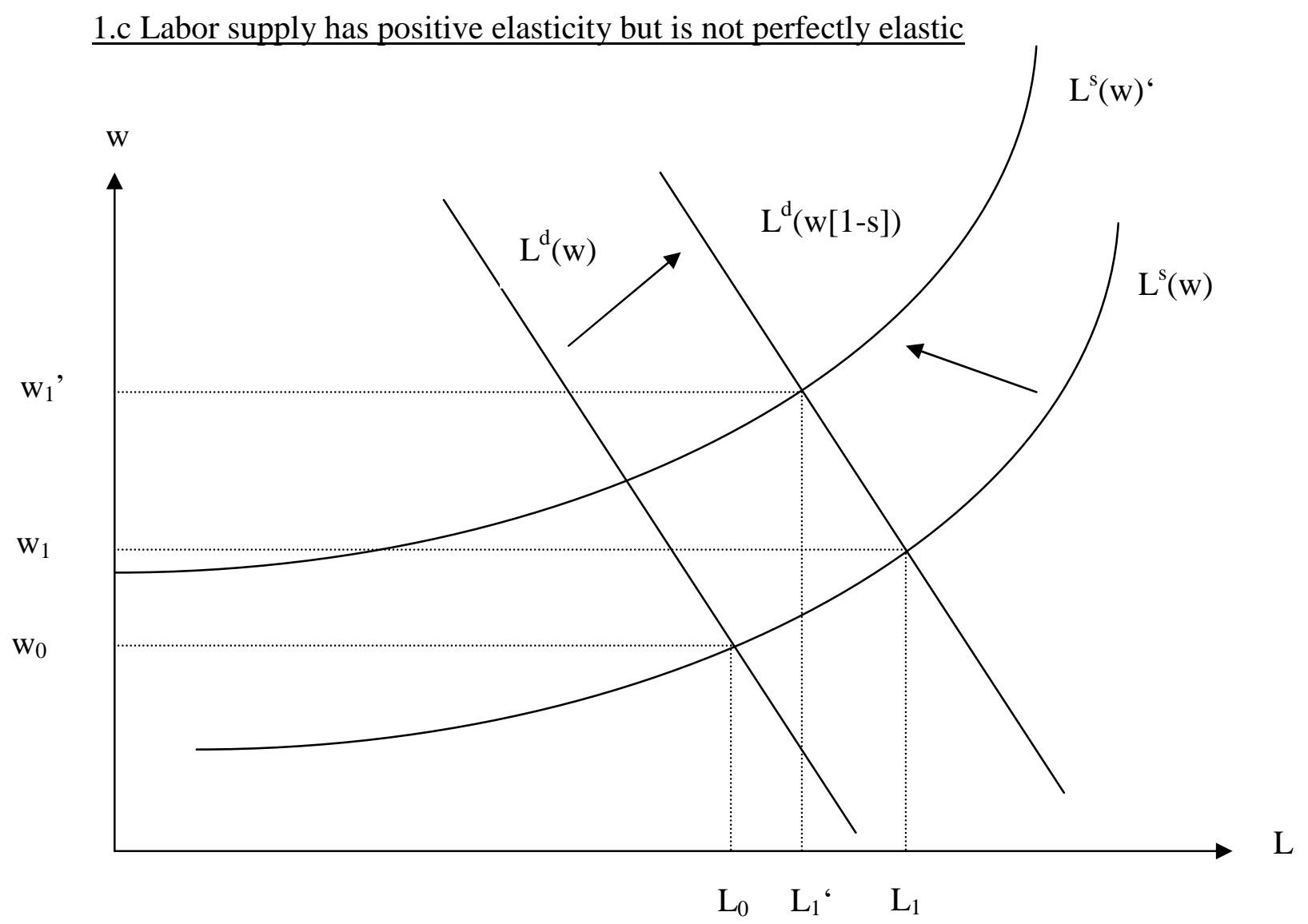


TABLES

Table 1. Descriptive statistics.

Panel A: full sample

\begin{tabular}{lccccc}
\hline Variable & Obs & Mean & Std. Dev. & Min & Max \\
\hline INFORMAL & 138 & 37.99 & 11.57 & 16.80 & 68.30 \\
EPL & 146 & 1.56 & 1.03 & 0 & 3.60 \\
TAX & 138 & 39.51 & 9.14 & 8.22 & 77.45 \\
BENEFIT & 132 & 20.53 & 19.32 & 0 & 80.00 \\
BNFT_DUR & 129 & 7.39 & 6.36 & 0 & 24.00 \\
DENSITY & 102 & 32.18 & 22.31 & 1.30 & 94.00 \\
GDP_GR & 159 & 4.56 & 4.53 & -11.2 & 20.80 \\
INFL_CH & 141 & 0.77 & 7.71 & -20.25 & 31.56 \\
EMP-POP-RAT & 154 & 55.19 & 7.04 & 31.5 & 69.50 \\
\hline \hline
\end{tabular}

Panel B: transition countries

\begin{tabular}{lccccc}
\hline \hline Variable & Obs & Mean & Std. Dev. & Min & Max \\
\hline INFORMAL & 70 & 36.86 & 11.42 & 16.80 & 68.30 \\
EPL & 71 & 2.37 & 0.55 & 0.38 & 3.60 \\
TAX & 76 & 38.43 & 5.75 & 23.00 & 53.20 \\
BENEFIT & 74 & 24.90 & 11.39 & 0 & 60.00 \\
BNFT_DUR & 74 & 11.02 & 5.46 & 0 & 24.00 \\
DENSITY & 69 & 40.79 & 20.78 & 13.17 & 94.00 \\
GDP_GR & 84 & 5.57 & 4.79 & -11.20 & 20.80 \\
INFL_CH & 73 & 0.87 & 9.21 & -20.25 & 31.56 \\
EMP-POP-RAT & 79 & 51.43 & 6.83 & 31.50 & 65.00 \\
\hline \hline
\end{tabular}

Panel C: Latin American countries

\begin{tabular}{lccccc}
\hline \hline Variable & Obs & Mean & Std. Dev. & Min & Max \\
\hline INFORMAL & 68 & 39.16 & 11.70 & 18.50 & 67.70 \\
EPL & 75 & 0.79 & 0.75 & 0 & 3.10 \\
TAX & 62 & 40.82 & 11.99 & 8.22 & 77.45 \\
BENEFIT & 58 & 14.96 & 25.20 & 0 & 80.00 \\
BNFT_DUR & 55 & 2.50 & 3.64 & 0 & 12.00 \\
DENSITY & 33 & 14.19 & 12.65 & 1.30 & 63.10 \\
GDP_GR & 75 & 3.43 & 3.95 & -10.89 & 13.20 \\
INFL_CH & 68 & 0.66 & 5.74 & -12.42 & 29.42 \\
EMP-POP-RAT & 75 & 59.15 & 4.74 & 49.10 & 69.50 \\
\hline \hline
\end{tabular}

Notes: INFORMAL is the dependent variable in the analysis; measures the share-size of the informal economy according to Schneider et al. (2010). Key independent variables: EPL measures stringency of employment protection legislation, TAX is the tax wedge on labor, BENEFIT is the size of unemployment benefits, BNFT_DUR is the duration of unemployment benefits, and DENSITY is union density. Control variables: GDP_GR is GDP growth between time $\mathrm{t}-1$ and $\mathrm{t}, \mathrm{INFL} \_\mathrm{CH}$ is change in inflation betwee time $\mathrm{t}-1$ and $\mathrm{t}$, and EMP-POP-RAT stands for employment-to-population ratio. 
Table 2. Raw correlations.

Panel A: full sample

\begin{tabular}{lcccccc}
\hline \hline & INFORM & EPL & TAX & BENEFIT & BNFT_D & DENSIT \\
\hline INFORMAL & 1 & & & & & \\
EPL & $-0.23^{*}$ & 1 & & & & \\
TAX & $-0.25^{*}$ & 0.14 & 1 & & & \\
BENEFIT & $-0.22^{*}$ & $0.18^{*}$ & 0.14 & 1 & & \\
BNFT_DUR & $-0.34^{*}$ & $0.58^{*}$ & 0.13 & $0.51^{*}$ & 1 & \\
DENSITY & $0.26^{*}$ & $0.43^{*}$ & $-0.30^{*}$ & $0.27^{*}$ & $0.37^{*}$ & 1 \\
GDP_GR & -0.03 & $0.17^{*}$ & -0.12 & -0.16 & -0.02 & -0.08 \\
INFL_CH & $0.18^{*}$ & -0.04 & -0.11 & -0.05 & -0.01 & 0.10 \\
EMP-POP-RAT & $0.31^{*}$ & $-0.53^{*}$ & $-0.17^{*}$ & $-0.27^{*}$ & $-0.60^{*}$ & $-0.38^{*}$ \\
\hline \hline
\end{tabular}

Panel B: transition countries

\begin{tabular}{lcccccc}
\hline \hline & INFORM & EPL & TAX & BENEFIT & BNFT_D & DENSIT \\
\hline INFORMAL & 1 & & & & & \\
EPL & -0.04 & 1 & & & & \\
TAX & $-0.47^{*}$ & $0.25^{*}$ & 1 & & & \\
BENEFIT & $-0.32^{*}$ & 0.17 & $0.27^{*}$ & 1 & & \\
BNFT_DUR & -0.24 & 0.22 & $0.27^{*}$ & $0.52^{*}$ & 1 & \\
DENSITY & $0.55^{*}$ & 0.18 & $-0.35^{*}$ & -0.06 & -0.03 & 1 \\
GDP_GR & 0.07 & -0.05 & $-0.34^{*}$ & -0.14 & $-0.23^{*}$ & -0.20 \\
INFL_CH & $0.26^{*}$ & 0.05 & -0.11 & -0.13 & 0.00 & 0.17 \\
EMP-POP-RAT & 0.21 & $-0.41^{*}$ & -0.18 & $-0.26^{*}$ & $-0.28^{*}$ & -0.11 \\
\hline \hline
\end{tabular}

Panel C: Latin American countries

\begin{tabular}{lcccccc}
\hline \hline & INFORM & EPL & TAX & BENEFIT & BNFT_D & DENSIT \\
\hline INFORMAL & 1 & & & & & \\
EPL & -0.21 & 1 & & & & \\
TAX & -0.20 & $0.38^{*}$ & 1 & & & \\
BENEFIT & -0.16 & -0.09 & 0.21 & 1 & & \\
BNFT_DUR & $-0.49 *$ & 0.05 & $0.57^{*}$ & $0.62^{*}$ & 1 & \\
DENSITY & -0.13 & -0.01 & $0.35^{*}$ & $0.56^{*}$ & $0.49^{*}$ & 1 \\
GDP_GR & -0.13 & 0.02 & 0.05 & $-0.33^{*}$ & $-0.33^{*}$ & -0.19 \\
INFL_CH & 0.07 & -0.05 & -0.16 & -0.02 & -0.24 & -0.22 \\
EMP-POP-RAT & $0.47^{*}$ & 0.04 & $-0.50^{*}$ & -0.14 & $-0.51^{*}$ & -0.25 \\
\hline \hline
\end{tabular}

Note: Asterisks denote statistical significance at the $5 \%$ level. 
Table 3. Comparing different estimation methods: OLS, RE, and FE results.

\begin{tabular}{|c|c|c|c|}
\hline $\begin{array}{l}\text { Dependent var: } \\
\text { INFORMAL }\end{array}$ & $\begin{array}{l}\text { (1) } \\
\text { OLS }\end{array}$ & $\begin{array}{l}\text { (2) } \\
\mathrm{RE}\end{array}$ & $\begin{array}{l}(3) \\
\mathrm{FE}\end{array}$ \\
\hline EPL & $\begin{array}{l}-2.638 \\
(1.943)\end{array}$ & $\begin{array}{c}0.396 \\
(0.856)\end{array}$ & $\begin{array}{l}1.375^{*} \\
(0.717)\end{array}$ \\
\hline TAX & $\begin{array}{c}-0.675^{* * * *} \\
(0.174)\end{array}$ & $\begin{array}{c}0.056 \\
(0.066)\end{array}$ & $\begin{array}{c}0.136 * * \\
(0.063)\end{array}$ \\
\hline BENEFIT & $\begin{array}{l}-0.027 \\
(0.064)\end{array}$ & $\begin{array}{l}-0.080^{*} \\
(0.047)\end{array}$ & $\begin{array}{l}-0.087 \\
(0.056)\end{array}$ \\
\hline BNFT_DUR & $\begin{array}{l}-0.323 \\
(0.272)\end{array}$ & $\begin{array}{l}-0.253^{*} \\
(0.130)\end{array}$ & $\begin{array}{l}-0.104 \\
(0.114)\end{array}$ \\
\hline DENSITY & $\begin{array}{c}0.176 * * * \\
(0.063)\end{array}$ & $\begin{array}{c}0.058 \\
(0.037)\end{array}$ & $\begin{array}{c}0.044 \\
(0.037)\end{array}$ \\
\hline LAC & $\begin{array}{c}6.499 \\
(6.180)\end{array}$ & $\begin{array}{c}0.666 \\
(4.748)\end{array}$ & \\
\hline INTERCEPT & $\begin{array}{c}64.703 * * * \\
(9.816)\end{array}$ & $\begin{array}{c}34.988 * * * \\
(5.853)\end{array}$ & $\begin{array}{c}28.317 * * * \\
(3.426)\end{array}$ \\
\hline $\begin{array}{l}\mathrm{R} 2 \\
\mathrm{~N}\end{array}$ & $\begin{array}{c}0.41 \\
85\end{array}$ & $\begin{array}{c}0.11^{\mathrm{a}} \\
85\end{array}$ & $\begin{array}{c}0.24^{\mathrm{b}} \\
85\end{array}$ \\
\hline $\begin{array}{l}\text { Diagnostics } \\
\text { Breusch\&Pagan chi2(1) } \\
\text { Prob>chi2 } \\
\text { Hausman chi2(5) } \\
\text { Prob>chi2 }\end{array}$ & & $\begin{array}{c}35.15 \\
(0.000)\end{array}$ & $\begin{array}{c}22.68 \\
(0.000)\end{array}$ \\
\hline $\begin{array}{l}\text { Notes: Cluster robust sta } \\
\text { in parentheses. Asterisks } \\
\text { and } * * * \text { for } 1 \% \text {. } \\
\text { a overall R2. } \\
\text { b within R2. }\end{array}$ & $\begin{array}{l}\text { d errors (cl } \\
\text { lote signific }\end{array}$ & $\begin{array}{l}\text { ng on count } \\
\text { levels: * for }\end{array}$ & $\begin{array}{l}0, * * \text { for } 5 \% \\
7 \%\end{array}$ \\
\hline
\end{tabular}


Table 4. Comparing different models.

\begin{tabular}{|c|c|c|c|c|c|}
\hline Dependent var: & (1) & (2) & (3) & (4) & (5) \\
\hline INFORMAL & FE & FE & FE & FE & FE \\
\hline \multirow[t]{2}{*}{ EPL } & $1.375^{*}$ & 0.609 & 0.506 & 0.418 & 0.464 \\
\hline & $(0.717)$ & $(0.404)$ & $(0.410)$ & $(0.428)$ & $(0.442)$ \\
\hline \multirow[t]{2}{*}{ TAX } & $0.136 * *$ & -0.002 & 0.008 & -0.039 & 0.008 \\
\hline & $(0.063)$ & $(0.035)$ & $(0.031)$ & $(0.031)$ & $(0.031)$ \\
\hline \multirow[t]{2}{*}{ BENEFIT } & -0.087 & $-0.066^{*}$ & $-0.070 *$ & -0.061 & -0.086 \\
\hline & $(0.056)$ & $(0.037)$ & $(0.038)$ & $(0.042)$ & $(0.057)$ \\
\hline \multirow[t]{2}{*}{ BNFT_DUR } & -0.104 & -0.049 & -0.052 & -0.076 & -0.053 \\
\hline & $(0.114)$ & $(0.064)$ & $(0.066)$ & $(0.065)$ & $(0.070)$ \\
\hline \multirow[t]{2}{*}{ DENSITY } & 0.044 & 0.009 & 0.008 & & 0.007 \\
\hline & $(0.037)$ & $(0.016)$ & $(0.015)$ & & $(0.015)$ \\
\hline \multirow[t]{2}{*}{ YEAR2003 } & & $-1.191 * * *$ & $-1.537 * * *$ & $-1.646 * * *$ & $-1.606 * * *$ \\
\hline & & $(0.227)$ & $(0.238)$ & $(0.286)$ & $(0.305)$ \\
\hline \multirow[t]{2}{*}{ YEAR2007 } & & $-3.457 * * *$ & $-3.657 * * *$ & $-3.852 * * *$ & $-3.709 * * *$ \\
\hline & & $(0.361)$ & $(0.449)$ & $(0.476)$ & $(0.494)$ \\
\hline \multirow[t]{2}{*}{ LAC*YEAR2003 } & & & $1.301 * * *$ & $1.622 * * *$ & $1.404 * * *$ \\
\hline & & & $(0.473)$ & $(0.500)$ & $(0.512)$ \\
\hline \multirow[t]{2}{*}{ LAC*YEAR2007 } & & & 0.775 & 0.474 & 0.773 \\
\hline & & & $(0.765)$ & $(0.625)$ & $(0.764)$ \\
\hline \multirow[t]{2}{*}{ BENEFIT*LAC } & & & & & 0.038 \\
\hline & & & & & $(0.062)$ \\
\hline \multirow[t]{2}{*}{ INTERCEPT } & $28.317 * * *$ & $37.433 * * *$ & $37.338 * * *$ & $41.006 * * *$ & $37.641 * * *$ \\
\hline & $(3.426)$ & $(2.018)$ & $(1.911)$ & $(1.741)$ & $(2.093)$ \\
\hline $\mathrm{R} 2$ & 0.24 & 0.81 & 0.83 & 0.80 & 0.83 \\
\hline $\mathrm{N}$ & 85 & 85 & 85 & 105 & 85 \\
\hline
\end{tabular}

Notes: Regression with country fixed-effects. Cluster robust standard errors (clustering on countries) are reported in parentheses. Asterisks denote significance levels: * for $10 \%, * *$ for $5 \%$, and $* * *$ for $1 \%$. 
Table 5. Robustness checks with different additional controls.

\begin{tabular}{|c|c|c|c|c|c|c|}
\hline Dependent var: & (1) & (2) & (3) & (4) & $(5)$ & (6) \\
\hline INFORMAL & $\mathrm{FE}$ & $\mathrm{FE}$ & $\mathrm{FE}$ & $\mathrm{FE}$ & $\mathrm{FE}$ & FE \\
\hline \multirow[t]{2}{*}{ EPL } & 1.095 & 0.380 & $1.505 * *$ & $0.706 * * *$ & $1.181 * *$ & $0.545^{* *}$ \\
\hline & $(0.817)$ & $(0.454)$ & $(0.583)$ & $(0.241)$ & $(0.472)$ & $(0.232)$ \\
\hline \multirow[t]{2}{*}{ TAX } & $0.123^{*}$ & 0.004 & $0.085^{*}$ & -0.015 & $0.099 *$ & -0.030 \\
\hline & $(0.062)$ & $(0.029)$ & $(0.048)$ & $(0.020)$ & $(0.055)$ & $(0.035)$ \\
\hline \multirow[t]{2}{*}{ BENEFIT } & -0.074 & $-0.071 *$ & -0.064 & $-0.060 * *$ & -0.043 & $-0.046 * *$ \\
\hline & $(0.057)$ & $(0.038)$ & $(0.044)$ & $(0.022)$ & $(0.043)$ & $(0.021)$ \\
\hline \multirow[t]{2}{*}{ BNFT_DUR } & -0.128 & -0.062 & $-0.152 *$ & $-0.088 *$ & -0.085 & $-0.079 *$ \\
\hline & $(0.105)$ & $(0.062)$ & $(0.077)$ & $(0.046)$ & $(0.065)$ & $(0.046)$ \\
\hline \multirow[t]{2}{*}{ DENSITY } & 0.042 & 0.007 & 0.024 & 0.000 & 0.022 & 0.001 \\
\hline & $(0.039)$ & $(0.015)$ & $(0.027)$ & $(0.012)$ & $(0.027)$ & $(0.013)$ \\
\hline \multirow[t]{2}{*}{ YEAR2003 } & & $-1.669 * * *$ & & $-1.325 * * *$ & & $-1.117 * * *$ \\
\hline & & $(0.219)$ & & $(0.246)$ & & $(0.250)$ \\
\hline \multirow[t]{2}{*}{ YEAR2007 } & & $-3.663 * * *$ & & $-3.131 * * *$ & & $-2.928 * * *$ \\
\hline & & $(0.447)$ & & $(0.292)$ & & $(0.346)$ \\
\hline \multirow[t]{2}{*}{ LAC*YEAR2003 } & & $1.430 * * *$ & & 0.495 & & 0.030 \\
\hline & & $(0.479)$ & & $(0.420)$ & & $(0.482)$ \\
\hline \multirow[t]{2}{*}{ LAC*YEAR2007 } & & 0.976 & & 0.259 & & -0.216 \\
\hline & & $(0.802)$ & & $(0.563)$ & & $(0.797)$ \\
\hline \multirow[t]{2}{*}{ EMP-POP-RAT } & $-0.224 *$ & -0.062 & & & & \\
\hline & $(0.113)$ & $(0.064)$ & & & & \\
\hline \multirow[t]{2}{*}{ GDP_GR } & & & $-0.119 * * *$ & $-0.070 * * *$ & $-0.167 * * *$ & $-0.094 * * *$ \\
\hline & & & $(0.041)$ & $(0.017)$ & $(0.023)$ & $(0.022)$ \\
\hline \multirow[t]{2}{*}{ INFL_CH } & & & & & -0.003 & 0.002 \\
\hline & & & & & $(0.005)$ & $(0.003)$ \\
\hline INTERCEPT & $\begin{array}{c}41.233 * * * \\
(7.072)\end{array}$ & $\begin{array}{c}41.133 * * * \\
(3.569)\end{array}$ & $\begin{array}{c}31.962 * * * \\
(2.826)\end{array}$ & $\begin{array}{c}38.841 * * * \\
(1.428)\end{array}$ & $\begin{array}{c}32.085 * * * \\
(2.662)\end{array}$ & $\begin{array}{c}40.126 * * * \\
(1.968)\end{array}$ \\
\hline R2 & 0.31 & 0.83 & 0.52 & 0.90 & 0.67 & 0.92 \\
\hline $\mathrm{N}$ & 85 & 85 & 85 & 85 & 77 & 77 \\
\hline
\end{tabular}

Notes: Regression with country fixed-effects. Cluster robust standard errors (clustering on countries) are reported in parentheses. Asterisks denote significance levels: * for $10 \%, * *$ for $5 \%$, and $* * *$ for $1 \%$. 
Table 6. Comparing results for the two regions.

\begin{tabular}{|c|c|c|c|c|}
\hline Dependent var: & (1) & $(2)$ & (3) & (4) \\
\hline \multirow{2}{*}{ INFORMAL } & TEs & LAC & TEs & LAC \\
\hline & FE & $\mathrm{FE}$ & FE & $\mathrm{FE}$ \\
\hline \multirow[t]{2}{*}{ EPL } & 0.259 & 0.823 & $1.237 * * *$ & -2.862 \\
\hline & $(0.436)$ & $(0.918)$ & $(0.416)$ & (3.083) \\
\hline \multirow[t]{2}{*}{ TAX } & 0.079 & -0.068 & 0.053 & -0.033 \\
\hline & $(0.063)$ & $(0.044)$ & $(0.064)$ & (0.094) \\
\hline \multirow[t]{2}{*}{ BENEFIT } & -0.086 & -0.033 & 0.004 & -0.048 \\
\hline & $(0.051)$ & $(0.021)$ & $(0.046)$ & $(0.064)$ \\
\hline \multirow[t]{2}{*}{ BNFT_DUR } & -0.054 & 0.079 & -0.066 & $-1.091 * * *$ \\
\hline & $(0.058)$ & $(0.151)$ & $(0.062)$ & $(0.258)$ \\
\hline \multirow[t]{2}{*}{ DENSITY } & 0.027 & & 0.031 & \\
\hline & $(0.018)$ & & $(0.029)$ & \\
\hline \multirow[t]{2}{*}{ YEAR2003 } & $-1.413 * * *$ & -0.147 & & \\
\hline & $(0.271)$ & $(0.427)$ & & \\
\hline \multirow[t]{2}{*}{ YEAR2007 } & $-3.374 * * *$ & $-3.494 * * *$ & & \\
\hline & $(0.532)$ & $(0.414)$ & & \\
\hline \multirow[t]{2}{*}{ GDP_GR } & & & $-0.173 * * *$ & $-0.328 * * *$ \\
\hline & & & $(0.033)$ & $(0.052)$ \\
\hline \multirow[t]{2}{*}{ INFL_CH } & & & -0.004 & $-0.155^{* *}$ \\
\hline & & & $(0.004)$ & $(0.054)$ \\
\hline \multirow[t]{2}{*}{ INTERCEPT } & $34.458 * * *$ & $42.799 * * *$ & $31.192 * * *$ & $50.060 * * *$ \\
\hline & (3.392) & $(2.542)$ & (2.609) & $(5.298)$ \\
\hline $\mathrm{R} 2$ & 0.85 & 0.81 & 0.76 & 0.71 \\
\hline $\mathrm{N}$ & 58 & 46 & 55 & 39 \\
\hline
\end{tabular}

Notes: Regression with country fixed-effects. Cluster robust standard errors (clustering on countries) are reported in parentheses. Asterisks denote significance levels: * for $10 \%, * *$ for $5 \%$, and $* * *$ for $1 \%$. 


\section{Appendix - IZA-World Bank Panel Data Base}

The data used in the analysis is a combination of the database of the IZA Program Area "Labor markets in emerging and transition economies" and data on LAC countries provided by the World Bank. The first database is a new hand-collected dataset that provides essential information about the evolution of labor markets in the countries of Central and Eastern Europe and Central Asia. It includes 27 countries of the region and spans 14 years, 1995-2007 (data are collected every 4 years). The database contains 4 variables characterizing labor market outcomes, among them the employment to population ratio for workers aged between 15 and 59, and 6 variables describing labor market institutions and policies. There are 71 observations with complete data on these 10 variables, corresponding to 23 countries. The database of the World Bank provides information on essentially the same characteristics (except for expenditures on active labor market policies) for 25 countries from LAC region in 1999, 2003, and 2007. The details about the variables proxying for labor market institutions and polices are presented in what follows.

\section{Labor market institutions and policies in transition countries:}

- Employment protection legislation (EPL) index is based on version 2 of the OECD (2004) indicator and is a weighted average of 18 cardinal summary indicators of EPL strictness which can be gathered in three main areas: (i) employment protection of regular workers against individual dismissal; (ii) specific requirements for collective dismissals; (iii) regulation of temporary forms of employment.

- Active labor market policies (ALMP) - expenditures on active measures of labor market policies and public employment services as per cent of the country's GDP. Note: this variable is not available for LAC countries.

- Tax wedge on labor (TAX) is defined as the difference between the salary costs of a single "average worker" to their employer and the amount of net income ("take-homepay") that the worker receives. The taxes included are personal income taxes, compulsory social security contributions paid by both employees and employers, as well as payroll taxes for the few countries that have them; no consumption taxes are included.

- Union density (DENSITY) measures trade union density based on surveys, wherever possible. Where such data were not available, trade union membership and density 
were calculated using administrative data adjusted for non-active and self-employed members. $^{12}$

- Average unemployment benefit (BENEFIT) - the average benefit as percentage of the average wage. This deviates from the estimates typically used by the OECD because OECD replacement rates are not very meaningful in the transition countries due to the caps on the size of the benefit in many countries. ${ }^{13}$ For LAC countries, the variable is defined as the replacement ratio during the third month in unemployment.

- Maximum duration of unemployment benefits (BNFT_DUR) - defined as the period for which a person aged 40 years who has been employed for 22 years prior to unemployment receives unemployment benefits, wherever possible.

\footnotetext{
${ }^{12}$ A caveat concerning the quality of the union density data is due. There is a measurement problem in at least some of the selected countries. The World Bank notes, for instance, that "Armenia provides an example of the difficulty of interpreting union density figures in the CIS, with 75 percent union density by official estimates, but 80 percent of workers claiming to "have nothing in common" with trade unions, and half of those claiming to be totally uninformed about unions." For that reason the World Bank (2005b) did not provide any statistics on the coverage rates in the CIS countries. Whenever possible we therefore examined alternative estimates of unionization, especially in the CIS countries.

${ }^{13}$ In most countries of the region, the size of the unemployment benefit is related to past earnings. The rate may be as high as 100\% (like in Croatia at the end of the 1990s and in Ukraine in the mid-2000s). The problem is that there is an upper cap on the size of the benefit, which often implies, de facto, a flat rate benefit. For example, in the early 2000s the benefit replacement rate in Croatia was $100 \%$ of average salary in the last three months of employment, but the maximum was restricted to $900 \mathrm{Kn}$. Compared to the average wage of $3600 \mathrm{Kn}$, the amount is far less than the $100 \%$ replacement rate. Similarly, the unemployed in Russia can get $75 \%$ of their average wage in the last three months of employment, but there is a cap of 4900 RUR (or 110 Euro) as of mid-2009. Relative to the average wage in the economy (17441 RUR as of $1^{\text {st }}$ quarter 2009), the unemployment benefit is very low. The minimum benefit is almost negligible, amounting to 850 RUR only. It is essential that the minimum and maximum amounts of unemployment benefits are not established by a law, but are subject to government discretion.
} 


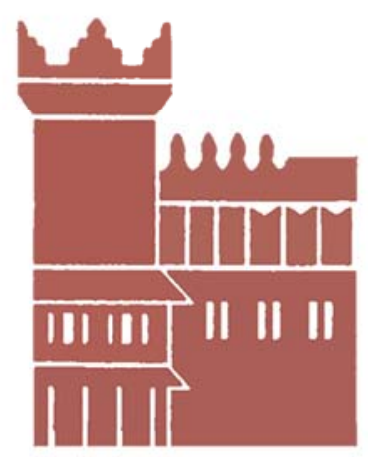

Alma Mater Studiorum - Università di Bologna DEPARTMENT OF ECONOMICS

Strada Maggiore 45

40125 Bologna - Italy

Tel. +39051 2092604

Fax +390512092664

http://www.dse.unibo.it 